\title{
EFFECTS OF SUGAR ALCOHOL AND PROTEINS ON THE SURVIVAL OF LACTOBACILLUS BULGARICUS LB6 DURING FREEZE DRYING
}

\author{
He Chen ${ }^{1}$, Shiwei Chen ${ }^{1 凶}$, Hongli Chen ${ }^{2}$, Yanyan $W^{2}$, Guowei Shu ${ }^{1}$ \\ ${ }^{1}$ College of Life Science and Engineering, Shaanxi University of Science and Technology \\ Xi'an, China \\ ${ }^{2}$ Xinjiang Shihezi Garden Dairy Co., Shihezi, China
}

\begin{abstract}
Background. Lactobacillus bulgaricus LB6 is a bacterium which was selected in the commercial yoghurt with high angiotensin converting enzyme (ACE) inhibitory activity. Preparation of concentrated starter cultures via freeze drying is of practical importance to dairy and food industries.

Material and methods. We optimized the optimal sugar alcohol and proteins for Lactobacillus bulgaricus $L B 6$ during the process of freeze drying using a Plackett-Burman design. In our initial tests survival rate and the number of viable cells were associated with the type of lyoprotectant used and so our optimization protocol focused on increasing survival rate. Substances that had previously had a protective effect during freeze drying were investigated, for example: mannitol, sorbitol, xylitol, meso-erythritol, lactitol, whey protein isolate 90, bovine serum albumin, and whey protein concentrate 80 and soy protein isolate 70 .

Results. We found that the optimum sugar alcohol and proteins for survival of Lactobacillus bulgaricus $L B 6$ were whey protein concentrate $(\mathrm{p}=0.0040$ for survival rate), xylitol ( $\mathrm{p}=0.0067$ for survival rate) and sorbitol ( $\mathrm{p}=0.0073$ for survival rate), they showed positive effect (whey protein concentrate and sorbitol) or negative effect (xylitol).

Discussion. The effectiveness of three chosen sugar alcohols and protein implied that they could be used as lyoprotectant for Lactobacillus bulgaricus LB6 in the further research, the optimal composition of sugar alcohol and protein for the lyoprotectant use must be established.
\end{abstract}

Key words: Lactobacillus bulgaricus, freeze drying, lyoprotectant, bacteria survival rate, sugar alcohol

\section{INTRODUCTION}

Lactobacillus bulgaricus is employed worldwide because it is able to produce lactic acid in the production of yoghurt, cheese and other fermented products (Guillouard et al., 2004; De Urraza and De Antoni, 1997) and is of vital importance to manufacture of fermented foods in combination with Streptococcus thermophilus. Although specific numbers are not mentioned in the definition, high levels of viable microorganisms are recommended in probiotic foods for efficacy (Knorr, 1998). During the preparation of the starter cultures, freeze drying become the most convenient and successful method of maximizing storage stability, viability, and activity of the bacterial cells (Berny and Hennebert, 1991; Lim et al., 2009) and it has been widely used in microbiology for many decades to stabilize and store cultures (Morgan and Vesey, 2009). However, not all strains survived during this process and quantitative viability rates as low as $0.1 \%$ have been reported (Abadias et al., 2001). The major causes of cell viability loss during freeze drying are related 
to ice crystal formation, membrane damage from high osmolarity due to high concentrations of internal solutes, macromolecule denaturation, and the removal of water, which affects properties of many hydrophilic macromolecules in cells (Allison et al., 1999; Chitra et al., 2003; De Paz et al., 2002; Thammavongs et al., 1996). For this reason, a variety of protective agents have been added to the drying media before freeze drying to protect the viability of probiotics during dehydration (Hubalek, 2003).

It is well documented that sugars have protective effects on lactic acid bacteria during freeze drying. For example, the trehalose has a high glass transition temperature $\left(\mathrm{T}_{\mathrm{g}}\right)$, it can rise the glass-phase transition temperature of cells and therefore viable cells can be protected by reaching the glassy phase without nucleating intracellular ice (Fowler and Toner, 2005). Apart from this, sorbitol (Carvalho et al., 2002), mannitol (Efiuvwevwere et al., 1999), sucrose (Carvalho et al., 2003), lactose (Higl et al., 2007), mannose (Carvalho et al., 2004) were reported to have the same impact. Amino acids may have the same protective effects as carbohydrates. A study by Mattern et al. (1999) showed that phenylalanine, arginine, and glycine can prevent denaturation during protein freeze drying. Several studies have suggested that some salt buffers, such as $\mathrm{NaCl}$ or $\mathrm{KCl}$ (Carvalho et al., 2003), sodium citrate (Kets et al., 2004; Kurtmann et al., 2009) and phosphate (Ohtake, 2004) can help to protect cells during freeze drying combined with other protectants. Besides, Buitink et al. (2000) found that proteins had a higher $\mathrm{T}_{\mathrm{g}}$ than sugar and suggested that proteins play an important role in glass formation. Hence, proteins, including skimmed milk, whey protein, blood serum, serum albumin, sodium caseinate and peptone are efficient desiccation protectants (Abadias et al., 2001; Hubalek, 2003; Sharma et al., 2014). All the above results showed that there was a lack of data on sugar alcohol and proteins was used as protectants for Lactobacillus bulgaricus during freeze drying, thus, there will be further insights into the studies of the effect of these various when applied in freeze drying.

In previous work, we screened 4 Lactobacillus strains that have high angiotensin converting enzyme (ACE) inhibitory activity from 28 probiotic strains.
The Lactobacillus reuteri, Lactobacillus bulgaricus (LB6), Lactobacillus rhamnosus and Lactobacillus helveticus showed high ACE inhibitory activity with $95.92 \%, 84.61 \%, 82.79 \%$ and $78.57 \%$, respectively (Chen et al., 2012). The aim of the present study was to investigate sugar alcohol and proteins that can potentially improve survival rate and the number of viable cells of Lactobacillus bulgaricus LB6 when freeze drying was employed.

\section{EXPERIMENTAL SECTION}

\section{Microorganism and media preparation}

Lactobacillus bulgaricus LB6 (LB6) were obtained from College of Life Science and Engineering, Shaanxi University of Science and Technology and inoculated three successive times with the MRS medium at $37^{\circ} \mathrm{C}$ for $24 \mathrm{~h}$ until the viability of bacteria stays stable. $3 \%$ active culture was added to the basal LAB growth media $(500 \mathrm{~mL})$ that containing substance that can promote cell proliferation, incubated at $37^{\circ} \mathrm{C}$, and then viable counts at optional incubation time. All the media were autoclaved at $121^{\circ} \mathrm{C}$ for $15 \mathrm{~min}$. The basal LAB growth medium contains $21 \mathrm{~g}$ of lactose, $4 \mathrm{~g}$ yeast extract powder, $10 \mathrm{~g}$ soya peptone, $9 \mathrm{~g}$ trehalose, $12 \mathrm{mg}$ leucine and $1000 \mathrm{~mL}$ water.

\section{Freeze drying medium}

The combinations of freeze drying medium (lyoprotectants) were the selected sugar alcohol and proteins added at their designed levels. Sugar alcohol: D-mannitol (min. 98.0\% LSbio, USA), D-sorbitol (min 98.0\%, LSbio, USA), xylitol (min. 99.0\%, LSbio, USA), meso-erythritol (min. 99.0\%, LSbio, China) and lactitol (min. 98.0\%, Food and feed additives, LSbio, China). All the sugar alcohols were autoclaved at $108^{\circ} \mathrm{C}$ for $15 \mathrm{~min}$ with $5 \%(\mathrm{w} / \mathrm{w})$. The proteins: whey protein isolate 90 (WPI 90, Hilmar 9410 WPI90, USA), whey protein concentrate 80 (WPC 80 , Hilmar 8010 WPC80, USA) and soy protein isolate 70 (SPI 70, Shanghai Yancui Import and Export Co., Ltd., China) were sterilized using $0.45 \mu \mathrm{m}$ membrane filtration with $5 \%(\mathrm{w} / \mathrm{w})$, and the bovine serum albumin V (BSA $\mathrm{V}$, LSbio, USA) in solution of $2.5 \%(\mathrm{w} / \mathrm{w})$. These protectants were mixed with $L B 6$ cells at the ratio of 1:1 $(\mathrm{w} / \mathrm{w})$ (The shortage was supplemented by phosphate buffer) in freezed vials. 


\section{Vacuum freeze drying}

After incubation, LB6 cell counts were determined immediately by the plate dilution method using MRS agar medium. The cells were harvested by centrifugation during the stationary phase of growth at $10000 \times \mathrm{g}$ for $15 \mathrm{~min}$ at $4^{\circ} \mathrm{C}$ and washed twice by centrifugation and resuspended in the same volume of each medium with $0.9 \% \mathrm{NaCl}$ solution. The cells were prefrozen at $-40^{\circ} \mathrm{C}$ for $12 \mathrm{~h}$ after protective agents (the selected sugar alcohol and proteins) were added, and then freeze dried at $-55^{\circ} \mathrm{C}, 6.93 \mathrm{~Pa}$ for $24 \mathrm{~h}$ using a vacuum freeze dryer.

\section{Determination of cell counts}

Before centrifugation, the samples were taken from each suspension and the number of CFU/mL (Colony Forming Units) was determined by the plate dilution method using MRS agar medium, and the plates were carried out at $37^{\circ} \mathrm{C}$ for $48 \mathrm{~h}$, the viable cells of $L B 6$ were conducted in triplicates by plating on the plate, and the results obtained were considered as "before freeze drying" data. The freeze-dried powder were reconstituted to their original pre-freeze dried volumes by adding sterile saline solution and number of viable cells counted as above, these results mean "after freeze drying" data.

\section{Calculation of survival}

Survival rate $(\%)=(\mathrm{CFU} / \mathrm{mL}$ after freeze drying $/$ $\mathrm{CFU} / \mathrm{mL}$ before freeze drying) $\times 100 \%$

\section{Screening of sugar alcohol and proteins using Plackett-Burman design}

The Plackett-Burman design was employed to determine the effect of the selected sugar alcohol (mannitol, sorbitol, xylitol, meso-erythritol, and lactitol) and proteins (WPI 90, BSA V, WPC 80 and SPI 70) on survival rate and viability of $L B 6$ after freeze drying at a lower and a higher level coded as $(+1)$ and $(-1)$ (Table 1), respectively. The design matrix is shown in Table 2 where the effect can be seen of 11 variables (including two error terms: X6 and X11, in order to estimate the standard deviation) was investigated in 12 independent experimental runs.
Table 1. Sugar alcohol and proteins at different levels in Plackett-Burman design

\begin{tabular}{clcc}
\hline Variables & $\begin{array}{l}\text { Medium } \\
\text { components }\end{array}$ & $\begin{array}{c}\text { Lower level } \\
\%\end{array}$ & $\begin{array}{c}\text { Higher level } \\
\%\end{array}$ \\
\hline X1 & mannitol & 5 & 10 \\
X2 & sorbitol & 5 & 10 \\
X3 & xylitol & 5 & 10 \\
X4 & meso-erythritol & 5 & 10 \\
X5 & lactitol & 5 & 10 \\
X7 & WPI 90 & 5 & 10 \\
X8 & BSA V & 2.5 & 5 \\
X9 & WPC 80 & 5 & 10 \\
X10 & SPI 70 & 5 & 10 \\
\hline
\end{tabular}

\section{Statistical analysis}

The statistical analysis was performed by the Design-Expert (Version, 8.0.6) to identify the significant variables and their corresponding coefficients, so that the various levels managed to obtain a desired output. Hence, F-value, sum of squares, p-value and confidence interval (CI) was analysed using the experimental results of survival rate and viability. The experimental results (response function, $\mathrm{Y}$ ) were fitted to first order multiple regression equations (eq. (1)) using coded level $(-1$ or +1$)$ of the variables $\left(\mathrm{X}_{\mathrm{i}}\right)$ :

$$
\mathrm{Y}=\mathrm{b}_{\mathrm{o}}+\sum_{\mathrm{i}=1}^{\mathrm{k}} \mathrm{b}_{\mathrm{i}} \mathrm{x}_{\mathrm{i}}+\varepsilon
$$

\section{RESULTS}

\section{The experimental design and results}

The relation between protective agents and survival rate of $L$. bulgaricus $L B 6$ is shown in Table 2. The survival rate and viability of freeze-dried $L B 6$ cells were represented by $\mathrm{Y} 1(\%)$ and $\mathrm{Y} 2\left(\times 10^{10} \mathrm{CFU} / \mathrm{g}\right)$, respectively. The survival rate was calculated by an equation containing the factor of viable cells, where the influence of protective agents was measured by the survival rate. All of the protective agents had different effects on the cells so that when the agents were changed, the survival rate and viability of $L B 6$ also changed. 
Chen, H., Chen, S., Chen, H., Wu, Y., Shu, G. (2015). Effects of sugar alcohol and proteins on the survival of Lactobacillus bulgaricus LB6 during freeze drying. Acta Sci. Pol. Technol. Aliment., 14(2), 117-124. DOI: 10.17306/J.AFS.2015.2.13

Table 2. Experimental design and results of the Plackett-Burman tests

\begin{tabular}{rrrrrrrrrrrrrr}
\hline Run & $\mathrm{X} 1$ & $\mathrm{X} 2$ & $\mathrm{X} 3$ & $\mathrm{X} 4$ & $\mathrm{X} 5$ & $\mathrm{X} 6$ & $\mathrm{X} 7$ & $\mathrm{X} 8$ & $\mathrm{X} 9$ & $\mathrm{X} 10$ & $\mathrm{X} 11$ & $\mathrm{Y} 1, \%$ & $\mathrm{Y} 2, \times 10^{10} \mathrm{CFU} / \mathrm{g}$ \\
\hline 1 & 1 & -1 & 1 & -1 & -1 & -1 & 1 & 1 & 1 & -1 & 1 & 5.3 & 0.424 \\
2 & 1 & 1 & -1 & 1 & -1 & -1 & -1 & 1 & 1 & 1 & -1 & 65.67 & 4.29 \\
3 & -1 & 1 & 1 & -1 & 1 & -1 & -1 & -1 & 1 & 1 & 1 & 55.97 & 3.75 \\
4 & 1 & -1 & 1 & 1 & -1 & 1 & -1 & -1 & -1 & 1 & 1 & 10.01 & 0.915 \\
5 & 1 & 1 & -1 & 1 & 1 & -1 & 1 & -1 & -1 & -1 & 1 & 41.79 & 2.8 \\
6 & 1 & 1 & 1 & -1 & 1 & 1 & -1 & 1 & -1 & -1 & -1 & 4.88 & 0.331 \\
7 & -1 & 1 & 1 & 1 & -1 & 1 & 1 & -1 & 1 & -1 & -1 & 43.28 & 3.64 \\
8 & -1 & -1 & 1 & 1 & 1 & -1 & 1 & 1 & -1 & 1 & -1 & 19.4 & 1.26 \\
9 & -1 & -1 & -1 & 1 & 1 & 1 & -1 & 1 & 1 & -1 & 1 & 44.78 & 3.31 \\
10 & 1 & -1 & -1 & -1 & 1 & 1 & 1 & -1 & 1 & 1 & -1 & 50 & 3.37 \\
11 & -1 & 1 & -1 & -1 & -1 & 1 & 1 & 1 & -1 & 1 & 1 & 34.33 & 2.61 \\
12 & -1 & -1 & -1 & -1 & -1 & -1 & -1 & -1 & -1 & -1 & -1 & 11.63 & 1.07 \\
\hline
\end{tabular}

\section{Effect of the various on survival of $L$. bulgaricus $L B 6$}

Analysis of variance (ANOVA) was performed to estimate the effect on growth of each factor (Table 3). In the ANOVA, "p-value" less than 0.1000 indicate that the terms are significant. Thus, the variables WPC 80 (X9) (p=0.0040), xylitol (X3) $(\mathrm{p}=0.0067)$ and sorbitol $(X 2)(p=0.0073)$ had the most significant impact on the survival rate and they can protect the cell better than the other agents tested in this study. Furthermore, the positive or negative of coefficients in Final Equation in Terms of actual factors means that all the selected variables have positive or negative effect on viable counts (Y1), and the trends of the $95 \%$

Table 3. Result of ANOVA of variables for Survival rate (Y1)

\begin{tabular}{lrrrrr}
\hline \multicolumn{1}{c}{ Source } & Sum of squares & df & Mean square & \multicolumn{1}{c}{ F-value } & p-value \\
\hline X1 - mannitol & 83.9523 & 1 & 83.9523 & 12.3662 & 0.0722 \\
X2 - sorbitol & 915.2533 & 1 & 915.2533 & 134.8168 & 0.0073 \\
X3 - xylitol & 996.6341 & 1 & 996.6341 & 146.8042 & 0.0067 \\
X4 - meso-erythritol & 328.8627 & 1 & 328.8627 & 48.4415 & 0.0200 \\
X5 - lactitol & 180.9633 & 1 & 180.9633 & 26.6559 & 0.0355 \\
X7 - WPI 90 & 0.1121 & 1 & 0.1121 & 0.0165 & 0.9095 \\
X8 - BSA V & 122.3685 & 1 & 122.3685 & 18.0249 & 0.0513 \\
X9 - WPC 80 & 1703.1301 & 1 & 1703.1301 & 250.8711 & 0.0040 \\
X10 - SPI 70 & 584.0865 & 1 & 584.0865 & 86.0359 & 0.0114 \\
\hline
\end{tabular}


confidence interval of the variables (Fig. 1,2 and 3) can also demonstrated this, the equation have been shown as follow (determination coefficient $\mathrm{R}^{2}=0.9972$ ):

$$
\begin{gathered}
\mathrm{Y} 1=32.25-2.64 \mathrm{X} 1+8.73 \mathrm{X} 2-9.11 \mathrm{X} 3+5.23 \mathrm{X} 4 \\
+3.88 \mathrm{X} 5+0.097 \mathrm{X} 7-3.19 \mathrm{X} 8+11.91 \mathrm{X} 9 \\
+6.98 \mathrm{X} 10
\end{gathered}
$$

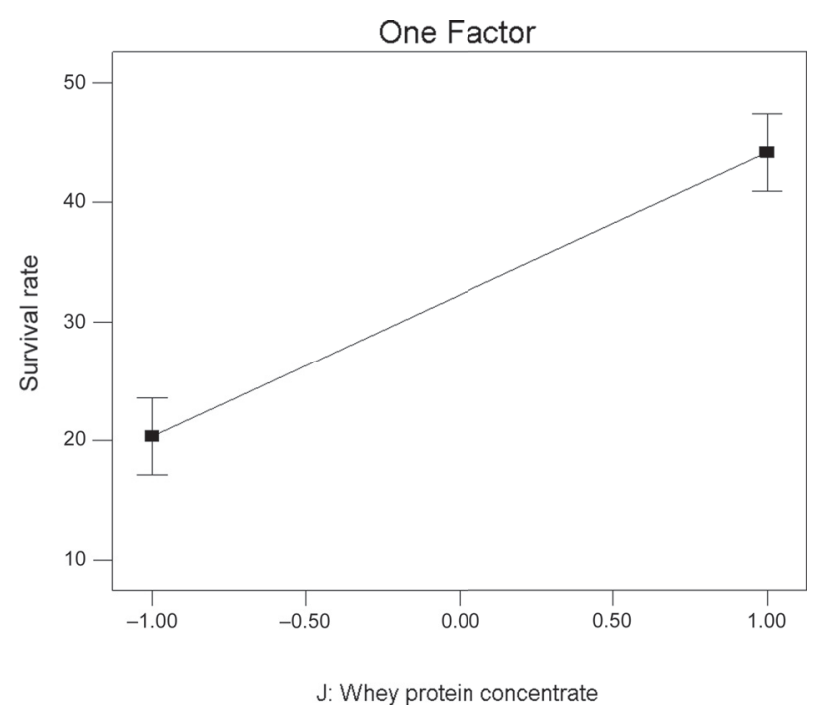

Fig. 1. $95 \%$ confidence interval of WPC 80 (X9)

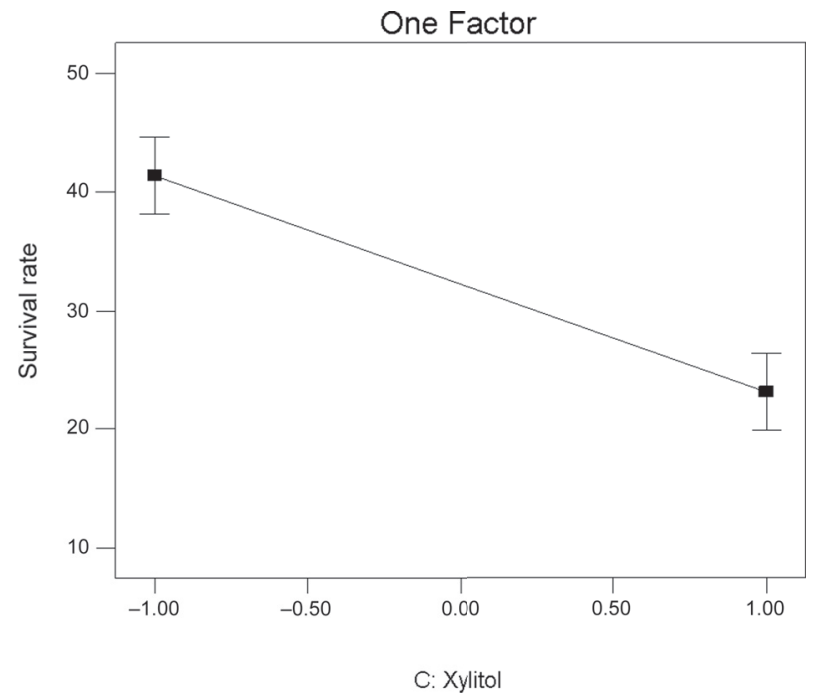

\section{Effect of the various on viability} of $L$. bulgaricus $L B 6$

The Table 4 showed the ANOVA of the variables for viability of freeze-dried $L B 6$. As the Table 4 showed, the relative importance of the variables was as follows: $\mathrm{X} 9>\mathrm{X} 3>\mathrm{X} 2>\mathrm{X} 4>\mathrm{X} 10>\mathrm{X} 1>\mathrm{X} 8>\mathrm{X} 5>\mathrm{X} 7$. Out of
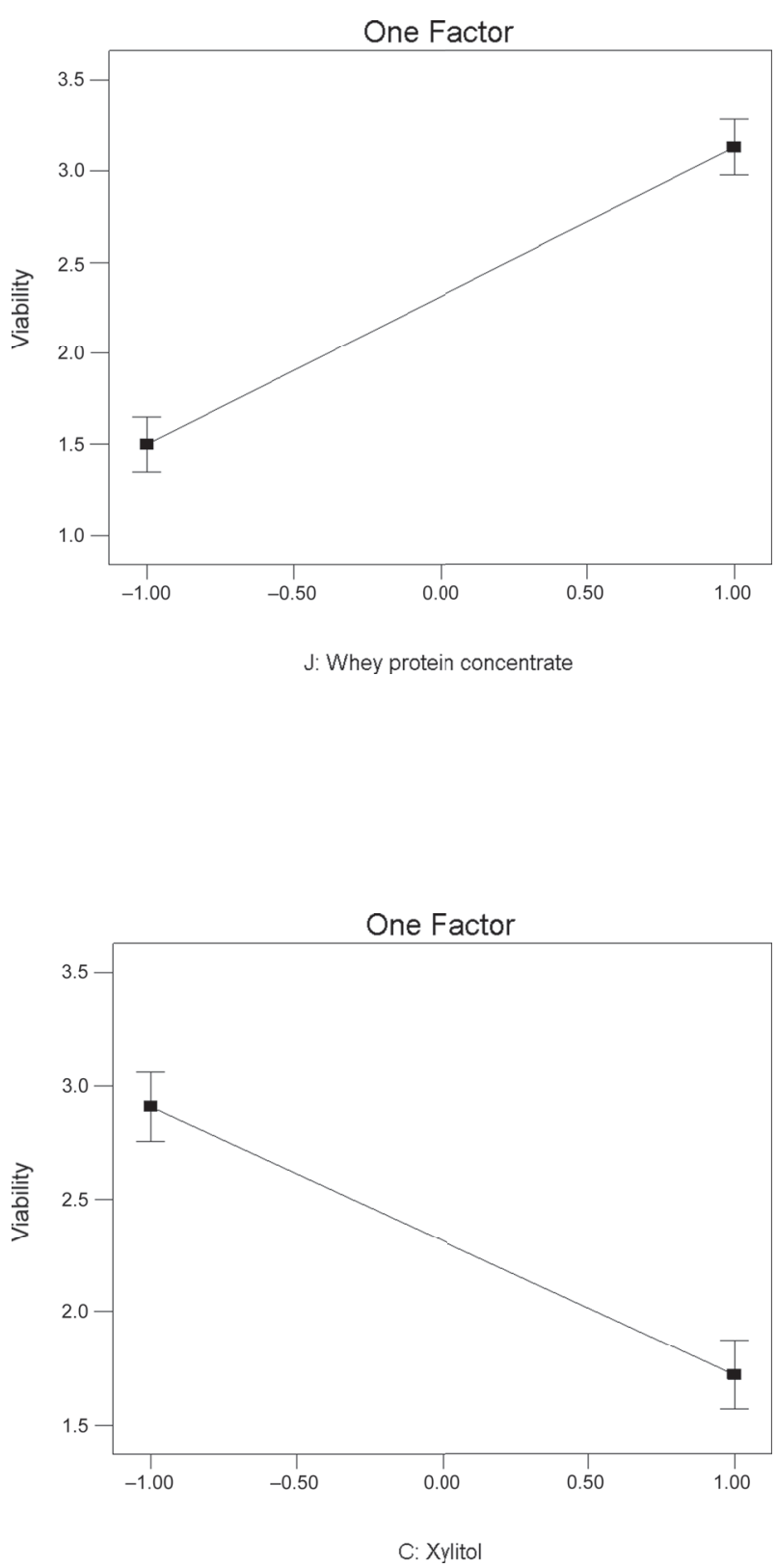

Fig. 2. $95 \%$ confidence interval of xylitol (X3) 

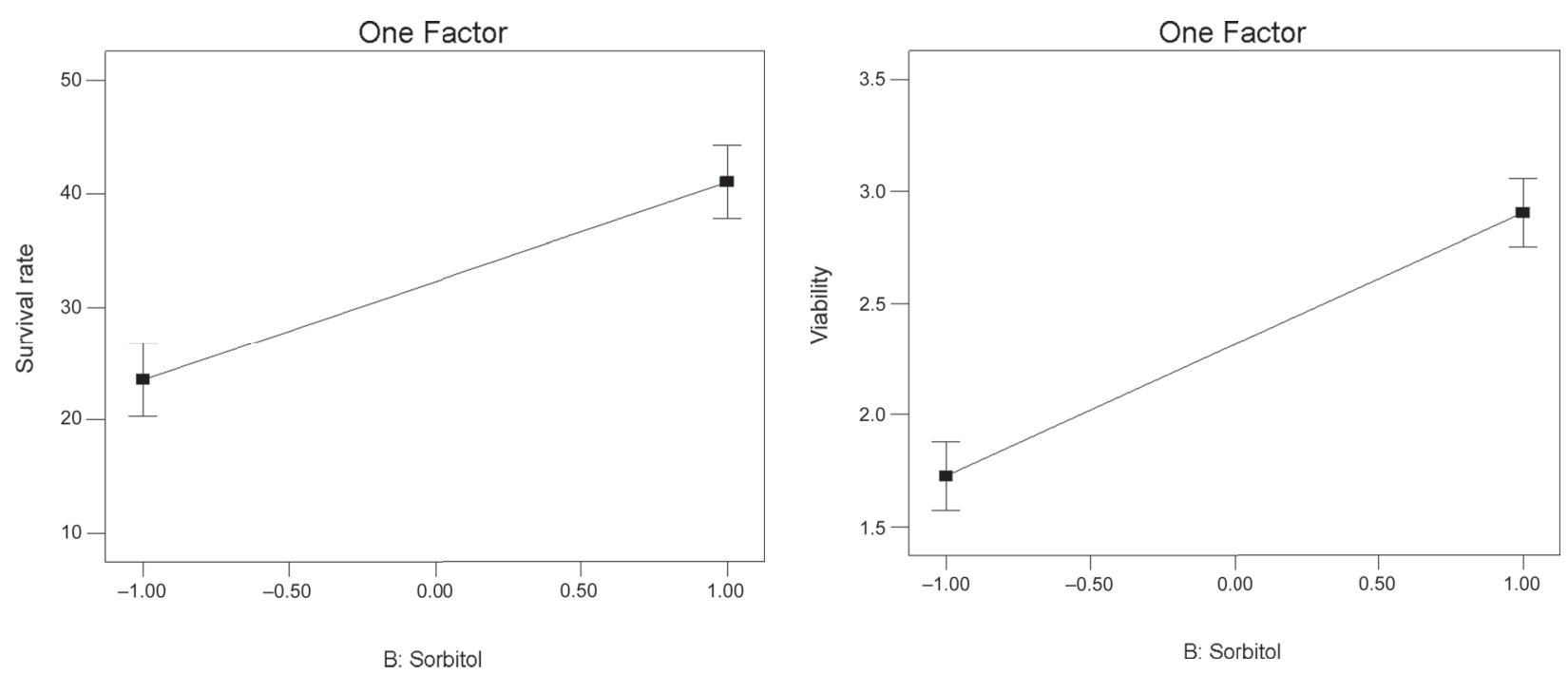

Fig. 3. $95 \%$ confidence interval of sorbitol (X2)

Table 4. Result of ANOVA of variables for viability of freeze-dried LB6 (Y2)

\begin{tabular}{lccccc}
\hline \multicolumn{1}{c}{ Source } & Sum of squares & df & Mean square & F-value & p-value \\
\hline x1 - mannitol & 1.0267 & 1 & 1.0267 & 68.0992 & 0.0144 \\
x2 - sorbitol & 4.1678 & 1 & 4.1678 & 276.4473 & 0.0036 \\
x3 - xylitol & 4.2364 & 1 & 4.2364 & 281.0004 & 0.0035 \\
x4 - meso-erythritol & 1.8096 & 1 & 1.8096 & 120.0327 & 0.0082 \\
x5 - lactitol & 0.2920 & 1 & 0.2920 & 19.3704 & 0.0479 \\
X7 - WPI 90 & 0.0160 & 1 & 0.0160 & 1.0604 & 0.4114 \\
X8 - BSA V & 0.9185 & 1 & 0.9185 & 60.9262 & 0.0160 \\
X9 - WPC 80 & 8.0001 & 1 & 8.0001 & 530.6433 & 0.0019 \\
X10 - SPI 70 & 1.7787 & 1 & 1.7787 & 117.9809 & 0.0084 \\
\hline
\end{tabular}

the above factors, WPC 80 (X9) $(\mathrm{p}=0.0019)$, xylitol $(\mathrm{X} 3)(\mathrm{p}=0.0035)$ and sorbitol $(\mathrm{X} 2)(\mathrm{p}=0.0036)$ can affect the survival rate of $L B 6$ significantly. The $95 \%$ confidence interval of the variables showed as Figures 1,2 and 3. The WPC 80 and sorbitol have positive effect on the viability of freeze-dried $L B 6$ when added in the designed amount, but xylitol negative.

\section{DISCUSSION}

Freeze drying has been used to manufacture lactic acid bacteria powders for decades and is based upon sublimation. Typically, cells are first frozen and then dried by sublimation under high vacuum (Santivarangkna et al., 2007). It has been shown that cellular inactivation occurs mostly at the freezing step (Tsvetkov and Brankova, 1983). Therefore, many studies have focused on 
approaches to minimize damage by protective agents. Sugars, including some sugars alcohol were reported to help maintain the tertiary protein structure in the absence of water by forming hydrogen bonds with proteins during drying (Leslie et al., 1995). In this case, the selected xylitol and sorbitol showed very excellent results on protect the $L B 6$ from injuring by the absence of water. In addition, proteins can also decrease the injury of cells by preventing cellular damage by stabilizing the cell membrane constituents (Castro et al., 1995). This indicates that the proteins were valid and suitable to be protecting agents for the L. bulgaricus.

\section{CONCLUSIONS}

In this study mannitol, sorbitol, xylitol, meso-erythritol, lactitol, WPI 90, BSA V, WPC 80 and SPI 70 were investigated as protective agents for freeze-dried $\mathrm{Lac}$ tobacillus bulgaricus LB6. Studying the protect ability for $L B 6$ used a Plackett-Burman design and demonstrated that WPC 80, xylitol and sorbitol have a significant impact on the survival and viability of $L B 6$ during freeze drying and all of the above protective agents were demonstrated to have a positive effect, except xylitol. These results provide the basis for further optimization of the lyoprotectant mixture during freeze drying of Lactobacillus bulgaricus.

\section{ACKNOWLEDGMENT}

The project was partly supported by the Science and technology assistance project of Xinjiang (No. 2014AB033), the science and technology plan project of Xi'an city (No. NC1317 (1)), the Science and Technology Research Development plan project of Shaanxi Province, China (No. 2014K01-17-07). Science and Technology Major Project of Xianyang city (No. 2014k01-15), Shaanxi Province, China.

\section{REFERENCES}

Abadias, M., Benabarre, A., Teixido, N., Usall, J., Vi, I. (2001). Effect of freeze drying and protectants on viability of the biocontrol yeast Candida sake. Int. J. Food Microbiol., 65(3), 173-182.

Abadias, M., Teixido, N., Usall, J., Benabarre, A., Vinas, I. (2001). Viability, efficacy, and storage stability of freeze-dried biocontrol agent Candida sake using different protective and rehydration media. J. Food Protect., 64(6), 856-861.

Allison, S. D., Chtang, B., Randolph, T. W., Carpenter, J. F. (1999). Hydrogen bonding between sugar and protein is responsible for inhibition of dehydration-induced protein unfolding. Arch. Biochem. Biophys., 365(8), 289-298.

Berny, J. F., Hennebert, G. L. (1991).Viability and stability of yeast cells and filamentous fungus spores during freeze-drying: effects of protectants and cooling rates. Mycologia, 83(6), 805-815.

Buitink, J., van den Dries, I. J., Hoekstra, F. A., Alberda, M., Hemminga, M. A. (2000). High critical temperature above $\mathrm{T}_{\mathrm{g}}$ may contribute to the stability of biological systems. Biophys. J., 79(2), 1119-1128.

Carvalho, A. S., Silva, J., Ho, P., Teixeira, P., Malcata, F. X., Gibbs, P. (2002). Survival of freeze-dried Lactobacillus plantarum and Lactobacillus rhamnosus during storage in the presence of protectants. Biotechnol. Lett., 24(19), 1587-1591.

Carvalho, A. S., Silva, J., Ho, P., Teixeira, P., Malcata, F. X., Gibbs, P. (2003). Effects of addition of sucrose and salt, and of starvation upon thermotolerance and survival during storage of freeze-dried Lactobacillus delbrueckii ssp. bulgaricus. J. Food Sci., 68(8), 2538-2541.

Carvalho, A. S., Silva, J., Ho, P., Teixeira, P., Malcata, F. X., Gibbs, P. (2004). Effects of various sugars added to growth and drying media upon thermotolerance and survival throughout storage of freeze-dried Lactobacillus delbrueckii ssp. bulgaricus. Biotechnol. Prog., 20(1), 248-254.

Castro, H., Teixeira, P., Kirby, R. (1995). Storage of lyophilized cultures of Lactobacillus bulgaricus under different relative humidities and atmospheres. Appl. Microbiol. Biot., 44(1-2), 172-176.

Chen, H., Ji, Z., Shu, G. W., Xing, H. N. (2012). Effect of probiotic Lactobacillus strains on angiotensin I converting enzyme inhibitory activity from fermented goat milk. Adv. Mater. Res., 531, 442-445.

Chitra, T., Lian, Y., Suryanarayanan, R. (2003). Effective inhibition of mannitol crystallization in frozen solutions by sodium chloride. Pharm. Res. (Dordrecht), 20(4), 660-667.

De Paz, R. A., Dale, D. A., Barnett, C. C., Carpenter, J. F., Gaertner, A. L., Randolph, T. W. (2002). Effects of drying methods and additives on the structure, function, and storage stability of subtilisin; role of protein conformation and molecular mobility. Enzyme Microb. Tech., 31(6), 765-774. 
Chen, H., Chen, S., Chen, H., Wu, Y., Shu, G. (2015). Effects of sugar alcohol and proteins on the survival of Lactobacillus bulgaricus LB6 during freeze drying. Acta Sci. Pol. Technol. Aliment., 14(2), 117-124. DOI: 10.17306/J.AFS.2015.2.13

De Urraza, P., De Antoni, G. (1997). Induced cryotolerance of Lactobacillus delbrueckii subsp. bulgaricus LBB by preincubation at suboptimal temperatures with a fermentable sugar. Cryobiology, 35(2), 159-164.

Efiuvwevwere, B. J. O., Gorris, L. G. M., Smid, E. J., Kets, E. P. W. (1999). Mannitol-enhanced survival of Lactococcus lactis subjected to drying. Appl. Microbiol. Biotechnol., 51(1), 100-104.

Fowler, A., Toner, M. (2005). Cryo-injury and biopreservation. Ann. NY Acad. Sci., 1066, 119-135.

Guillouard, I., Lim, E., Van de Guchte, M., Grimaldi, C., Penaud, S., Maguin, E. (2004). Tolerance and adaptative acid stress of Lactobacillus delbrueckii ssp. bulgaricus. Lait., 84(1-2), 1-6.

Higl, B., Kurtmann, L., Carlsen, C. U., Ratjen, J., Forst, P. (2007). Impact of water activity, temperature, and physical state on the storage stability of Lactobacillus paracasei ssp. paracasei freeze-dried in a lactose matrix. Biotechnol. Prog., 23(4), 794-800.

Hubalek, Z. (2003). Protectants used in the cryopreservation of microorganisms. Cryobiology, 46(3), 205-229.

Kets, E. P. W., Upelaar, P. J., Hoekstra, F. A., Vromans, H. (2004). Citrate increases glass transition temperature of vitrified sucrose preparations. Cryobiology, 48(1), 46-54.

Knorr, D. (1998). Technology aspects related to microorganisms in functional foods. Trends Food Sci. Techn., 9(8-9), 295-306.

Kurtmann, L., Carlsen, C. U., Risbo, J., Skibsted, L. H. (2009). Storage stability of freeze-dried Lactobacillus acidophilus (La-5) in relation to water activity and presence of oxygen and ascorbate. Cryobiology, 58(2), $175-180$

Leslie, S. B., Israeli, E., Lighthart, B., Crowe, J. H., Crowe, L. M. (1995). Trehalose and sucrose protect both membranes

Received - Przyjęto: 27.09.2014

Accepted for print - Zaakceptowano do druku: 21.01.2015

and proteins in intact bacteria during drying. Appl. Environ. Microb., 61(10), 3592-3597.

Lim, C. M., Rahim, R. A., Ho, Y. W., Ariff, A. B. (2009). Formulation of protective agents for improvement of Lactobacillus salivarius I 24 survival rate subjected to freeze drying for production of live cells in powderized form. Food Bioproc. Technol., 2(4), 431-436.

Mattern, M., Winter, G., Kohnert, U. (1999). Formulation of proteins in vacuum-dried glasses: Process and storage stability in sugar-free amino acid systems. Pharm. Dev. Technol., 4(2), 199-208.

Morgan, C., Vesey, G. (2009). Freeze-drying of microorganisms encyclopaedia of microbiology (Third Edition; pp. 162-173). Oxford, UK: Academic Press.

Ohtake, S. (2004). Effect of sugar-phosphate mixtures on the stability of DPPC membranes in dehydrated systems. Cryobiology, 48(1), 81-89.

Santivarangkna, C., Kulozik, U., Foerst, P. (2007). Alternative drying processes for the industrial preservation of lactic acid starter cultures. Biotechnol. Progr., 23(2), 302-315.

Sharma R., Sanodiya, B. S., Thakur, G. S., Jaiswal, P., Sharma, A., Bisen, P. S. (2014). Standardization of lyophilization medium for Streptococcus thermophilus subjected to viability escalation on freeze drying. Microbiol. Res., 5(1), 1-3.

Thammavongs, B., Corroler, D., Panoff, J. M., Auffray, Y., Boutibonnes, P. (1996). Physiological response of Enterococcus faecalis JH2-2 to cold shock: growth at low temperatures and freezing/thawing challenge. Lett. Appl. Microbiol., 23(6), 398-402.

Tsvetkov, T., Brankova, R. (1983). Viability of micrococci and lactobacilli upon freezing and freeze-drying in the presence of different cryoprotectants. Cryobiology, 20(3), $318-323$.

For citation - Do cytowania

Chen, H., Chen, S., Chen, H., Wu, Y., Shu, G. (2015). Effects of sugar alcohol and proteins on the survival of Lactobacillus bulgaricus LB6 during freeze drying. Acta Sci. Pol. Technol. Aliment., 14(2), 117-124. DOI: 10.17306/J.AFS.2015.2.13 